\title{
Pengaruh Terapi Meditasi (Dzikir) terhadap Tingkat Stres pada Lansia
}

\section{Suci Sutioningsih ${ }^{1}$, Sri Suniawati ${ }^{2}$, Suhuda Hamsanikeda ${ }^{3}$}

1. Rumah Sakit Mata Undaan, Surabaya

2. Universitas Nurul Jadid, Probolinggo

3. Universitas Nurul Jadid, Probolinggo

\section{Abstract}

Stress is a condition which produced by an environment alteration which received as a case challenging, threatening or damaging the equilibrium or dynamic state of a person. Stress experienced by humans can be derived from various sources from within of a person, family, and environment. On an elderly is not uncommon that stress can often occur. To overcome and relieve a stress, there are several ways can be do such as gymnastics, reflection, laughter therapy, aromatherapy, and meditation. The purpose of this study was to find out the meditation therapy (dzikir) effect to the stress levels of elderly. This study uses the analytical method with a One-Group Pre-TestPosttest Design. The sampling method used is purposive sampling. Population use all elderly at the Mojopahit Elderly Institution of Mojokerto at 2012 with a sample of 20 respondents, the data obtained from the dissemination of questionnaires. The result of the respondents study included to the middle criteria are about 2 people (10\%) and the low criteria are about 18 people (90\%). In the data analysis, researcher use a t-test with the provisions of $p<a(p=0.015$; $a=0.05)$. From the result of research known 
$p=0.015<0.05$, its mean there is an effect of meditation therapy (dzikir) implementation to the stress levels of elderly. So the meditation therapy (dzikir) should be applied at the elderly institution as a daily activity for the elderly, especially to relieve a stress.

Keywords : stress, meditation therapy, elderly

\section{Abstrak}

Stres merupakan suatu keadaan yang dihasilkan oleh perubahan lingkungan yang diterima sebagai suatu hal yang menantang, mengancam atau merusak terhadap keseimbangan atau keadaan dinamis seseorang. Stres yang dialami manusia dapat berasal dari berbagai sumber dari dalam diri seseorang, keluarga, dan lingkungan. Pada seseorang yang sudah lanjut usia, tidak jarang stres ini bisa saja sering terjadi. Untuk mengatasi dan meringankan stres, ada beberapa cara yang bisa dilakukan antara lain senam, refleksi, terapi tertawa, aromaterapi, dan meditasi. Tujuan dari penelitian ini adalah untuk mengetahui pengaruh terapi meditasi (dzikir) terhadap tingkat stres pada lansia. Penelitian ini menggunakan metode analitik dengan One-Group Pra-test-postttest Desain. Metode sampling yang digunakan adalah purposive sampling. Populasi yang digunakan adalah semua lansia di Panti Werdha Mojopahit Mojokerto tahun 2012 dengan besar sampel 20 responden, data yang diperoleh dari penyebaran kuesioner. Hasil dari penelitian 
responden termasuk dalam kriteria stres sedang sekitar 2 orang (10\%) dan kriteria rendah sebanyak 18 orang (90\%). Pada analisa data, peneliti menggunakan uji $\mathrm{t}$ ( $t$-test) dengan ketentuan $\rho<a(\rho=0,015 ; a=0,05)$. Dari hasil penelitian diketahui $\rho=0,015<0,05$ yang artinya ada pengaruh pelaksanaan terapi meditasi (dzikir) terhadap tingkat stres pada lansia. Pentingnya terapi meditasi (dzikir) untuk diterapkan pada lansia yang mengalami stress.

Kata kunci: Stres, terapi meditasi, lansia 


\section{Pendahuluan}

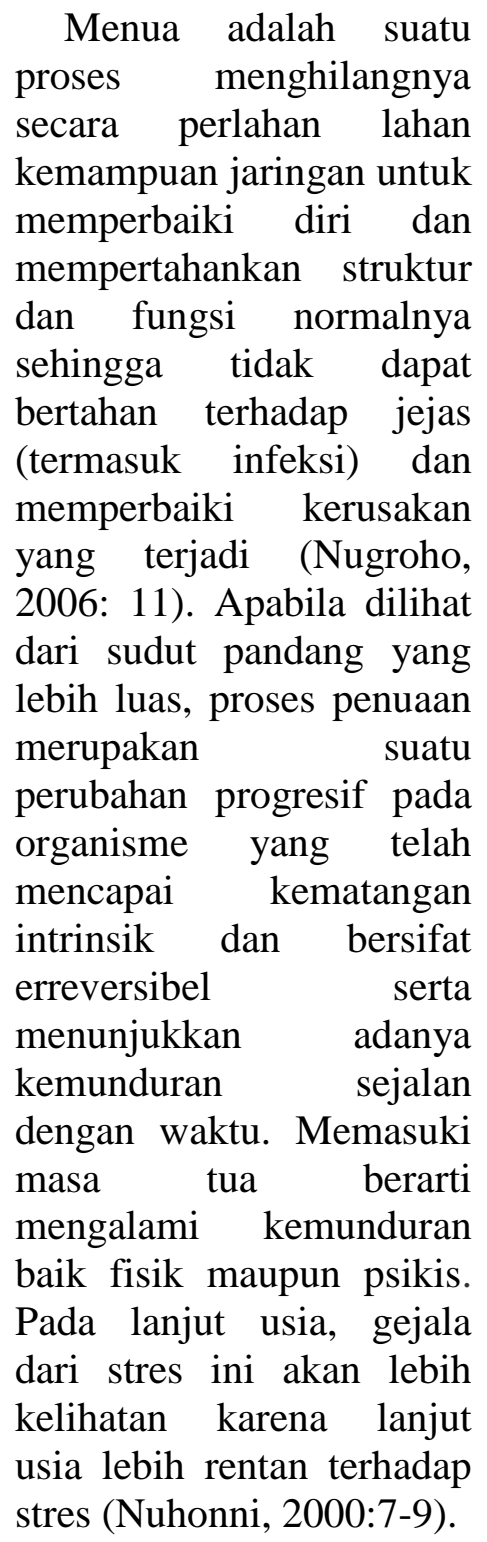

Stres yang dirasakan oleh lanjut usia dapat mempengaruhi

kehidupannya karena dapat menimbulkan hilangnya selera makan, bicara berlebihan atau juga menarik diri, gejala muka yang memerah atau tubuh yang menggigil kedinginan, dan masih banyak lagi. Stres dapat menimbulkan dampak negatif, misalnya: pusing, tekanan darah tinggi, mudah marah, sedih, sulit berkonsentrasi, nafsu makan berubah, tidak bisa tidur ataupun merokok terus menerus. Selain itu, stres juga dapat menyebabkan seseorang menjadi lebih sensitive / peka terhadap depresi, kecelakaan virus, masuk angin, serangan jantung, bahkan kanker. Singkatnya stres pada lanjut usia adalah kondisi tidak seimbang, terjadi menyeluruh pada tubuh yang tercipta bila orang yang bersangkutan melihat ketidaksepadanan antara keadaan dan sistem sumber daya biologis, psikologis dan sosial, dimana terjadi penurunan kemampuan 
$\begin{aligned} & \text { mempertahankan hidup } \\ & \text { yang akhirnya } \\ & \text { mengkibatkan kematian. }\end{aligned}$

Usaha terapi dan pencegahan stres pada prinsipnya ada tiga jenis yaitu psikologis, melalui kepribadian untuk mengubah pengertian (persepsi) dan pandangan hidup, latihan relaksasi, serta psikoterapi. Yang kedua yaitu obat (medis), melalui pemberian obat anti cemas. Dan yang terakhir yakni melalui faktor lingkungan, dengan cara penciptaan lingkungan hidup yang damai. Ada banyak cara yang bisa dilakukan untuk mengatasi dan mencegah stres itu sendiri, terutama yang terjadi pada lansia, misalnya yaitu minum air putih, makan, tidur, seks, dan bisa juga melakukan meditasi (Hartono, 2007). Meditasi sangat membantu membersihkan pikiran kita dan meningkatkan

konsentrasi. Telah terbukti bahwa meditasi selama lima belas menit sama dengan kita beristirahat selama satu jam.

Metode

Penelitian ini menggunakan penelitian pra eksperimen pra-pascatest dalam satu kelompok (OneGroup Pra-test-postttest Desain). Ciri dari penelitian ini adalah mengungkapkan hubungan sebab akibat dengan cara melibatkan satu kelompok subjek. Kelompok subjek diobservasi sebelum dilakukan intervensi, kemudian diobservasi lagi setelah intervensi dengan jumlah populasi 48 Orang. Sampel yang digunakan dalam penelitian ini adalah 20 Orang, peneliti menggunakan teknik purposive sampling dalam penentuan sampel, diaman didalam penentuan sampel peneliti memeliki beberapa kriteria yang telah ditetapkan peneliti. Tempat penelitian di panti werdha Mojopahit Mojokerto 
Hasil Penelitian

1. Data Umum

a. Karakteristik Resonden berdasarkan Agama

Tabel 1 Distribusi berdasarkan Agama
Berdasarkan data yang diperoleh pada tabel 1 di atas, menunjukkan bahwa sebelum dilakukan terapi meditasi diperoleh nilai sedang sebanyak $45 \%$, sedangkan rendah sebanyak 55\%. Hal ini dapat diartikan bahwa tingkat stres

\begin{tabular}{cccc}
\hline No & Agama & F & \%ada \\
\hline 1 & Islam & 20 & 39tęap \\
2 & Non & 0 & 60,72 \\
& Islam & & b
\end{tabular}

Berdasarkan hasil penelitian pada tabel 1 di atas, didapatkan sebagian besar responden dengan keyakinan atau agama Islam sebanyak 20 responden $(100 \%)$.

2. Data Khusus

a. Tingkat stres pada lansia sebelum dilakukan terapi meditasi (Pre test)

Tabel 2 Nilai tingkat stres sebelum dilakukan terapi meditasi (dzikir) pada lansia di Panti Werdha Mojopahit Mojokerto.

Kategori F

\begin{tabular}{ccc}
\hline Tinggi & 0 & $0 \%$ \\
Sedang & 9 & $45 \%$ \\
Rendah & 11 & $55 \%$ \\
\hline $\mathrm{N}$ & 20 & $100 \%$ \\
\hline
\end{tabular}

100

b. Tingkat stres pada lansia setelah dilakukan terapi meditasi (Post test)

Tabel 2 Nilai tingkat stres setelah dilakukan terapi meditasi (dzikir) pada lansia di Panti Werdha Mojopahit Mojokerto

\begin{tabular}{lcc}
\hline Kategori & $\mathrm{F}$ & $(\%)$ \\
& & \\
\hline Tinggi & 0 & $0 \%$ \\
Sedang & 2 & $10 \%$ \\
Rendah & 18 & $90 \%$ \\
$\mathrm{~N}$ & 20 & $100 \%$ \\
\hline Berdasarkan & data & yang \\
diperoleh pada tabel & 3, diatas \\
dapat diketahui bahwa setelah \\
dilakukan terapi meditasi \\
(dzikir) pada \\
didapatkan nilai sedang 10\%, \\
dan rendah sebanyak 90\%. \\
Hal ini dapat diartikan bahwa \\
setelah dilakukan terapi \\
meditasi (dzikir) nilai tingkat \\
stres lansia pada kategori \\
rendah naik dari sebelumnya
\end{tabular}


ada $55 \%$ dan sekarang menjadi $90 \%$.

c. Pengaruh terapi meditasi terhadap tingkat stres pada lansia di Panti Werdha Mojopahit Mojokerto

Tabel 4 Nilai Pengaruh terapi meditasi terhadap tingkat stres pada lansia di Panti Werdha Mojopahit Mojokerto

\begin{tabular}{|c|c|c|c|c|}
\hline \multirow[t]{2}{*}{ Kategori } & \multicolumn{4}{|c|}{$\begin{array}{l}\text { Tingkat stres sebelum dan sesudah } \\
\text { dilakukan terapi meditasi (dzikir) }\end{array}$} \\
\hline & Pre test & $\%$ & Post Test & $\%$ \\
\hline Tinggi & 0 & 0 & 0 & 0 \\
\hline Sedang & 9 & 45 & 2 & 10 \\
\hline Rendah & 11 & 55 & 18 & 90 \\
\hline Std. Deviasi & & & & \\
\hline Sig. & \multicolumn{4}{|c|}{$<0,05$} \\
\hline
\end{tabular}

Berdasarkan data yang diperoleh pada tabel 4, diatas dapat diketahui bahwa setelah dilakukan terapi meditasi (dzikir), terdapat perbedaan nilai pada tingkat stres lansia yaitu pada kategori sedang dan rendah. Sehingga terdapat pengaruh terapi meditasi (dzikir) terhadap tingkat stres pada lansia antara sebelum dan sesudah intervensi.

Hasil yang diperoleh dari uji statistik yang menggunakan uji t pada lansia yang mengalami stres yaitu di dapatkan t hitung 2,666 dan $\mathrm{t}$ tabel dengan $\alpha=$ 0,05 adalah 2,093 sehingga diperoleh $\mathrm{t}$ hitung 2,666 $>\mathrm{t}$ tabel 2,093 , maka H1 diterima yang berarti ada pengaruh pemberian terapi meditasi dzikir terehadap tingkat stres pada lansia. Sedangkan untuk nilai signifikansi (2-tailed) diperoleh hasil 0,015 yang berarti $0,015<$ 0,05 , maka $\mathrm{H} 1$ diterima yang berarti terdapat perbedaan tingkat stres pada lansia antara sebelum dan sesudah dilakukan terapi meditasi (dzikir). Hal ini menunjukkan bahwa terapi meditasi (dzikir) dapat mempengaruhi tingkat stres pada lansia.

\section{Pembahasan}

1. Tingkat stres pada lansia sebelum dilakukan terapi meditasi (dzikir)

Berdasarkan tabel 2 ternyata nilai rata-rata stres sebelum dilakukan terapi meditasi (dzikir) yaitu tidak terdapat nilai pada kategori tinggi hanya terdapat nilai pada kategori sedang $45 \%$ dan pada kategori rendah sebanyak $55 \%$. Jadi perbedaan nilai antara sedang dan rendah yaitu hanya 5\%. Karena memang pada saat ini belum dilakukan terapi meditasi (dzikir) pada lansia.

Diketahui ada beberapa faktor kemungkinan penyebab terjadi peningkatan / penurunan tingkat stres pada lansia di Panti Werdha Mojopahit Mojokerto. Menurut Gunawan (2001) yang dikutip oleh Hoiron, penyebab diantaranya adalah 
karena faktor perubahanperubahan secara biologis yang terjadi karena proses penuaan (Aging Proses), kesehatan yang menurun, kebosanan, tidak dikunjungi sanak saudara, dan masalahmasalah yang muncul dalam kehidupan sehari-hari.

Lansia di Panti Werdha Mojopahit Mojokerto sering mengalami kecemasan dan kehilangan peran diri, kependudukan sosial serta perpisahan dengan orangorang yang dicintai, dan tidak jarang banyak yang mengalami sakit, karena kesehatan yang menurun, serta banyak juga yang mempunyai hubungan yang tidak baik antar sesama lansia. Itu disebabkan karena faktor emosi. Dari segi spiritual memang tidak semua lansia bisa berdzikir secara lancar, dan harus perlu adanya tuntunan yang baik dari peneliti. Selain itu dari hasil wawancara peneliti dengan responden bahwa hampir sebagian besar lansia ditinggal oleh keluarga dan hidup sendiri. Sehingga tidak mempunyai penyemangat dalam hidupnya.
2. Tingkat stres pada lansia setelah dilakukan terapi meditasi (dzikir)

Berdasarkan tabel 3 hasil pengukuran tingkat stres pada lansia pada saat post test di dapatkan data bahwa nilai tingkat stres mengalami peningkatan yaitu pada kategori rendah yang sebelumnya ada $55 \%$, setelah dilakukan terapi jumlahnya menjadi 90\%. Jadi ada peningkatan nilai sebanyak $35 \%$, setelah dilakukan terapi meditasi selama 5 hari.

Menurut Brealey (2002) yang dikutip oleh Hoiron, menyatakan bahwa pada dasarnya terapi meditasi merupakan salah satu teknik terapi yang dapat mempengaruhi tubuh agar dapat berespon positif dan membuat tubuh menjadi lebih tenang dan rileks. Serta bermanfaat untuk perbaikan kesehatan, baik mental maupun fisik. Meditasi menurunkan kerentangan terhadap stres atau ketegangan dalam sistem syaraf, dan meditasi juga berfungsi sebagai suatu terapi pembantu untuk 
menumbuhkan kemampuan penyembuhan diri. Meditasi sebagai respon relaksasi, disadari dapat membendung aliran hormon stres dan memproduksi respon yang merupakan kebalikan dari respon melawan menghindar ataupun respon terhadap stres. Meditasi yang dilakukan secara teratur akan segera didikuti oleh penurunan kecepatan detak jantung yang signifikan , penurunan tekanan darah, sistem syaraf menjadi tenang dan perbaikan dari segala penyimpangan fungsi yang berhubungan dengan stres, antara lain Depresi, migren, dan insomnnia pada lansia.

Penurunan tingkat stres ini mempunyai nilai yang berbeda-beda, hal ini mungkin juga disebabkan banyak hal diantaranya ketidakseriusan dan keaktifan responden dalam melakukan terapi meditasi.

Dan ada beberapa responden yang melakukan terapi meditasi (dzikir) dengan baik, dan ada pula yang kurang bisa berdzikir, dan tidak jarang ada yang mengeluh kram pada kaki dan pinggang, kurangnnya konsentrasi dalam memfokuskan perhatian ketika bermeditasi, mungkin keadaan inilah yang membedakan terjadinya perbedaan penurunan tingkat stres pada lansia antara satu dengan yang lainnya. Tetapi ada juga yang semangat mengikuti terapi ini, karena memang dari mereka yang khusyu' beribadah. Serta selalu aktif setiap hari mengikuti terapi meditasi. Hal inilah yang menyebabkan nilai tingkat stres berbeda antara sebelum dan sesudah dilaksanakan terapi.

3. Pengaruh terapi meditasi (dzikir) terhadap tingkat stres pada lansia di Panti Werdha Mojopahit Mojokerto

Hasil perhitungan statistik menggunakan uji $\mathrm{t}$ melalui program windows SPSS for release 16.0 diperoleh hasil $\rho$ $=0,015<0,05$ yang berarti H1 diterima. Sehingga dapat disimpulkan bahwa terdapat perbedaan nilai tingkat stres pada lansia antara sebelum dan sesudah pelaksanaan terapi meditasi. Jadi, terdapat pengaruh pelakasanaan terapi meditasi (dzikir) terhadap 
tingkat stres pada lansia di Panti Werdha Mojopahit Mojokerto.

Menurut shafi'i (2008) yang dikutip oleh Hoiron bahwa, meditasi itu sendiri jika dilaksanakan secara rutin maka akan menyebabkan terjadi perubahan rata-rata denyut jantung sebesar $25 \%$ sementara itu pada tingkat stres akan terjadi penurunan rata-rata $5-10 \%$ tingkat stres setelah bermeditasi. Terlihat dari penurunan tingkat stres lansia yang signifikan.

Dari penelitian ini terbukti bahwa terdapat penurunan tingkat stres pada lansia yang berarti ada pengaruh terhadap tingkat stres lansia antara sebelum dan sesudah pelaksanaan terapi meditasi (dzikir). Dan perbedaanperbedaan itu disebabkan oleh berbagai faktor internal maupun eksternal dari lansia itu sendiri. Faktor internal antara lain keadaan kesehatan lansia, masalah pribadi, dll. Sedangkan faktor eksternal bisa berasal dari lingkungan lansia itu sendiri atau dari orang lain yang mempengaruhi. Dari sini terlihat faktor agama dan kesehatan adalah faktor yang dominan yang mempengaruhi keefektifan pelaksanaan terapi meditasi (dzikir). Karena dari segi agama, tidak semua lansia bisa berdzikir secara lancar, sedangkan dari faktor kesehatan ada sebagian lansia yang mudah kram, atau tidak bisa duduk bersila, dan mengeluh pusing.

\section{Simpulan}

Adanya penurunan tingkat stres pada lansia di Panti Werdha Mojopahit Mojokerto setelah dilakukan terapi meditasi (dzikir) sebanyak $35 \%$. Sehingga meditasi bisa dijadikan pengobatan alternatif dalam penurunan stres pada usia lansia.

\section{Daftar Pustaka}

Anonim.

Meditasi.

(http://www.srcm.org/ce nters/as/id/MEDITASI. $\underline{\mathrm{htm}}$ diakses tanggal 12 Desember 2011).

Anonim. (2011). Bebaskan stres dengan cara meditasi.

(http://health.kompas.co $\underline{\mathrm{m} / \mathrm{read} / 2011 / 11 / 04 / 1113}$ 4416/Bebaskan.Stres.de ngan.Meditasi diakses tanggal 05 Desember 2011).

Farida, I \& Amalia, N. ( 2009

). Mengantisipasi

STROKE. Jogjakarta: BUKUBIRU. 
Hidayat, A.A. (2007). Metode Penelitian Keperawatan Dan Teknik Analisa Data. Jakarta: Salemba Medika.

Hoiron, ( 2010 ). Pengaruh terapi meditasi terhadap penurunan stres pada lansia. Di UPT Tresna Werdha Jombang : tidak dipublikasikan.

Keliat, B.A. ( 1997 ). Penatalaksanaan stress. Jakarta: EGC.

Munir, Zainal. 2017. "Analisis Pengaruh Pendidikan, Pendapatan Dan Pekerjaan Terhadap Motivasi Orangtua Dalam Kualitas Perawatan Anak Dengan HIV/AIDS WJK Kab.Probolinggo." Universitas

Muhammadiyah Jakarta.

Nursalam, ( 2003 ). Konsep dan Penerapan Metodelogi Penelitian Ilmu Keperawatan. Jakarta : Salemba Medika.

$\begin{array}{lr}\text { dan } & 2008) \text {. Konsep } \\ \text { Metodelogi } & \text { Penerapan } \\ \text { Ilmu Penelitian } \\ \text { Keperawatan. }\end{array}$

Jakarta : Salemba Medika.

Nugroho, W ( 2006 ). Keperawatan Gerontik \& Geriatrik. Jakarta: EGC.

Perry, Potter. (1999). Buku ajar fundamental keperawatan. edisi ke empat,buku kedokteran : EGC.

Rahayu, H.S ( 2007 ). Menopouse tanpa stres. Jakarta: Sunda kelapa pustaka.

Riduwan. (2006). Dasardasar statistika. Bandung ALFABETA.

Setiati, S ( 2000 ). Pedoman Praktis Perawatan untuk Pengasuh Orang Usia Lanjut. Jakarta : Bagian Ilmu Penyakit Dalam Fakultas Kedokteran Universitas Indonesia.

Stanley, M \& Beare, G P. ( 2002 ) . Buku ajar keperawatan gerontik. Jakarta: EGC.

Sugiono. (2001). Metode Penelitian Bisnis. Bandung : Alfabeta

Sutrani, L et all ( 2003 ). STROKE.Jakarta: 
Gramedia pustaka utama.

Rahayu.

Meditasi

mengendalikan level

stress.

(http://kampussamudrail

muhikmah.wordpress.co

$\mathrm{m} /$ category/meditasi-

mengendalikan-level-

stress/ di akses tanggal

25 November 2011).

Venerable Piyananda. Cara

bermeditasi.

(http://yumevie.multiply

.com/journal/item/28/Ca

ra_Meditasi diakses

tanggal 12 Desember

2011).

Yarnest. (2008). Panduan

Aplikasi Statistik.

Malang : Dioma 